\title{
Influence of the Art Education System of Russia on the Art Education System in Universities of Heilongjiang Province
}

\author{
Zhongfeng $\mathrm{Fu}$ \\ School of Fine Art and Design \\ Heihe University \\ Heihe, China
}

\begin{abstract}
With the change of art environment in our country, the traditional art education system in universities shows disadvantages. The art education system of Russia serves as a reference for the development of art education in China. This paper briefly summarizes the contents of art education system in Russia and discusses its influence on the art education system in universities of Heilongjiang Province from the three aspects of curriculum provision, teaching methods and teaching management, in order to learn the successful experience of art education system in Russia and promote the sustainable development of art education in universities of Heilongjiang Province.
\end{abstract}

Keywords-art education system of Russia; teaching management; teaching methods; curriculum provision; influence

\section{INTRODUCTION}

Under the background that the economic and cultural exchange between China and Russia becomes increasingly close, the learning of the art education field of China from the art education system in Russia is gradually thorough. To solve the problems existing in the current art education system of our country, we should integrate in the art education system in Russia to promote the long-term development of the art education industry in our country. Universities of Heilongjiang Province are instanced in this paper. Because Heilongjiang Province is adjacent to Russia, under the influence of factors like regional advantages, the art education system in Russia plays a benign role in promoting the development of the art education career in universities of Heilongjiang Province. With the economic development of our country, the educational field pays more and more attentions to art education. Universities in Heilongjiang Province have provided the specialty of fine arts. The construction of the art education system in the universities of Heilongjiang Province can be improved through the introduction of the scientific art education system in Russia and the ceaseless pursuit of innovative development.

\section{OVERVIEW ON THE ART EDUCATION SYSTEM IN RUSSIA}

The art education system in Russia has an important influence on the painting teaching of China, especially the sketch teaching system of Chistiakov. He attaches importance to the topicality and theatricality of art teaching and requires students to observe various phenomena in life and fully presents the characteristics of fine art works through the scientific attitude and personal understanding. The teaching system of Chistiakov has played an important guiding function on the construction of art education system in universities of China. The rigorous structure and realistic style in the art education system of Russia helps art educators of China obtain the systematic training. The learning of important contents in the art education system of Russia promotes art educators in Chinese universities to establish a more reasonable evaluation standard. As time goes on, the artistic exchange between China and Russia is frequent. Different from the traditional fine arts of China, the fine arts of Russia have strong characteristics of the times, which are fully embodied in the art education system of Russia. Under the different historical background between China and Russia, Chinese intellectuals insist learning from the cultural field of Russia. Maximoff also plays a crucial role in the construction of the art education system in Russia. The art education system of China forms under the guidance of its artistic thought. Maximoff is invited to conduct the oil painting training in China and has concluded a set of systematic teaching method through the teaching practice of training class. It promotes the initial shaping of the art education models in Chinese universities. The art education system in Russia under the artistic thought of Maximoff pays attention to training the world outlook and artistic view of students and imparts the contents of art education through the explanation of techniques in realistic painting. The art education system built by Maximoff has integrated the advanced teaching experience in the sketch teaching system of Chistiakov and the educational background of Russia at that time at the meantime forms the education system with personal characteristics through continuous creative efforts. Under the guidance of realistic and humanistic values, the art 
education system of Russia has promoted the prosperity and progress of art education throughout the world.

\section{THE INFLUENCE OF THE ART EDUCATION SYSTEM IN RUSSIA ON THE ART EDUCATION SYSTEM OF UNIVERSITIES IN HEILONGJiANG PROVINCE}

Most of universities in Heilongjiang Province have provided the specialty of fine arts. Universities in Heilongjiang Province have referred to the art education system in Russia by virtue of regional advantages, in order to improve the teaching efficiency of art curriculum. A complete teaching system requires the formulation of teaching objectives according to the physical truth of schools and the implementation via feasible measures. Influenced by the art education system in Russia, the art education system in universities of Heilongjiang Province pays attention to the reasonable provision of art curriculum in universities and the learning of scientific teaching methods of fine arts in universities and the improvement of teaching management of fine arts in universities, in order to build the education system that meets the requirements of the specialty of fine arts in universities of Heilongjiang Province.

\section{A. The Reasonable Provision of Art Curriculum in Universities}

The art education system in Russia is more meticulous and rigorous in the aspect of curriculum provision and follows the principle of rationality. For the teaching contents of elementary course and creative course of fine arts in universities, the art education system in Russia pays attention to the teaching of creative course and classifies courses like sketch, perspective and color as the elementary courses, which lay a solid foundation for independent creation. It plays a positive role in promoting the training of professional talents of fine arts. On the basis of the fine art system in Russia, universities in Heilongiiang Province can arrange the creative courses in different grades in the curriculum provision. They train the creative ability of students from junior grades and require students to create rough sketch via the method of proposition, achieve the aim of training the painting ability of students through repeated modification and completion. Basic courses and creative courses can promote each other. The reasonable provision of art curriculum in universities must base on the physical truth of art education in universities of Heilongjiang Province and the skillful arrangement of basic courses and creative courses. Under the guidance of teaching program, they strengthen students' painting ability and effectively improve the ability of students in independent creation. The reasonable provision of art curriculum in universities requires the art education system in universities of Heilongjiang Province clarifies the consistency between basic courses like sketch and color, learn the art education system in Russia and set the basic courses as the required courses. When arranging the learning of specialized fine arts, they take painting in class as the main teaching contents and reasonably arrange basic courses according to the change of time and avoid the phenomenon that the basic courses are interrupted by other courses. In the art education system in Russia, basic courses are taken in the afternoon and students of different grades take class together. Teachers will give professional guidance according to the learning characteristics of students. The phenomenon of extra class in spare time is also very prominent. The course of outdoor painting is arranged according to the weather. The basic courses are provided continuously in the whole semester to improve the participation degree of students in learning. Professional courses, creative courses and basic courses are divided according to time frame to avoid the boredom of students under the premise of keeping the consistency. In the art education system in Russia, the provision of reasonable teaching courses must guarantee the consistency of teachers' teaching. The art education system in universities of Heilongjiang Province must learn the pattern of universities in Russia that the courses are taught by certain teachers. According to the division of specialty and grade, teachers undertake the task of teaching fixed courses and ensure the teaching direction for students will not change. They must adhere to the efficient teaching objectives and make most students obtain the best learning effects in the unified teaching contents.

\section{B. The Scientific Methods of Art Teaching in Universities}

Realism is the teaching subject in the art education system in Russia, in order to show the concepts of realism through the realistic approach. The art education system in Russia follows the art teaching system in Europe, which takes the scientific observation as the key teaching points of the theory of painting and realizes the organic integration of classicism and reality in the teaching methods. In the formulation of teaching methods of fine arts, universities in Heilongjiang Province must fully refer to the art education system in Russia and adhere to the scientific educational concept. The teaching system of Chistiakov attaches importance to showing the structure consciousness of painting through such ways as sketch and train the ability of students in artistic aesthetics on the basis of solid drawing skills. Universities in Heilongjiang Province learn the scientific teaching methods in the art education system of Russia and aim at improving the drawing skills of students and strengthening their skills of fine arts. They arouse the enthusiasm of students in participating in fine art learning through abundant teaching methods and reform the traditional fixed teaching models and realize the ideal teaching effects in the diversified observation methods. The art education system in Russia takes the training of the creativity of students as the ultimate goal of teaching. The application of teaching methods also fully embodies in improving the creativity of students. Universities of Heilongjiang Province should strengthen the creativity of students in fine arts and adhere to the teaching objective of improving the painting skills of students and let students focus on studying a problem in the learning phase to guarantee the concentration of teaching. The explicit guidance of teachers promotes the creativity of students to develop in the orderly direction. Besides, they must accept the positive influence of the art education system in Russia on the art education field of Heilongjiang Province and correctly recognize the creativity of students in the specialty of fine arts. Under the support of powerful painting ability, 
students will furthest give play to the creativity through the integration of high-quality aesthetic appreciation with the true feeling. To acquire high quality learning efficiency, students must experience long-term practice. The scientific teaching methods of fine arts in universities help students to give play to the maximum value. Under the art education system in Russia, large numbers of painting masters come forward and have made significant contributions to the progress of the fine art field around the world. Through the effective learning of the art education system in Russia, universities in Heilongjiang Province can also train excellent students with a high level creative ability, in order to promote the development of art field in China. In the scientific teaching methods of fine arts, it's important to establish a good teaching concept. Instead of letting education stay in the basic teaching stage, they must standardize the painting skills of students and roundly train the consciousness of students in fine arts to promote the continuous growth of the art education system in universities of Heilongjiang Province through teaching methods with a clear direction.

\section{The Sound Management of Art Teaching in Universities}

The sound management of art teaching in universities can guarantee the smooth implementation of the art education system in Russia. In the art education system in Russia, the teaching assessment system is important. The effective teaching assessment link verifies whether the teaching results of teachers can realize and promotes teachers to make corresponding teaching adjustment according to the testing result, in order to improve teaching quality. Universities in Heilongjiang Province must continuously improve the teaching assessment system and guarantee the orderly execution of teaching management. In the real teaching management, they should grasp the important role of teaching assessment and learn the way of teaching assessment in the art education system in Russia and roundly test the fine art works of students through works show. Universities in Heilongjiang Province set the open day to collect the fine art works of students which must be tested by teachers and students in school as well as social person, in order to guarantee the comprehensiveness of teaching assessment. More attentions must be paid to the contents of teaching assessment in the art education system of universities in Heilongjiang Province. Teachers assign corresponding homework for students according to teaching requirements and the diversification of works is shown through works like sketch and oil paintings. The works of students in daily life must appear in the teaching process in different phases. Students share ideas with teachers and classmates in creation and ceaselessly improve the level of artistic creation via the communication and opinions of teachers and classmates. Displaying works of students plays the role of inspection. When the works fail to meet the requirements of most supervisors, the student will be unable to obtain a degree. The teaching circulation mechanism in the art teaching system of Russia embodies their rigorous attitudes toward art teaching and must be learnt by universities of Heilongjiang Province in the process of art education. The rigorous teaching management in the art education system of Russia promotes teachers to reach the best teaching state and stimulate the enthusiasm of students in active learning so that the good learning effects will be achieved. Learning from the standardized management system of art education must base on the physical truth of art education field in universities of Heilongjiang Province. Universities must formulate the teaching assessment system that conforms to the teaching standard and improve the enthusiasm of students in participating in artistic creation via displaying the excellent works of students. However, they must avoid the phenomenon that some students lose selfconfidence because of the poor effect of works show. Universities in Heilongjiang Province improve the art education system under the guidance of real teaching and reach the purpose of ideal teaching management.

\section{CONCLUSION}

With the rapid development of the specialty of fine arts in our country, universities in Heilongjiang Province also respond to the call and pay more attentions to the career of art education. They build the art education system with Heilongjiang characteristics and contribute to promoting cultural and ideological progress via learning the art education system in Russia. Under the profound influence of art education system in Russia, universities of Heilongjiang Province base on the physical truth of their development and integrate resources of art education in the two countries. Under the guidance of the art education system with characteristics of the times, they reasonably provide art curriculum, learn the scientific methods of art teaching and improve the management of art teaching, in order to promote the diversified development of art field of Heilongjiang Province and let Chinese fine arts go to the world.

\section{REFERENCES}

[1] Ping Pingfan, Yang Jia. Discussion on Heilongjiang Fine Arts Influenced by the Painting Style in Russia [J], Art Education, 2014(10): 211-211

[2] Cao Dan. Rethinking on the Traditional Art Teaching System in Russia [J], Hubei Institute of Fine Arts Journal, 2012(1): 109-112

[3] Li Maoquan. Analysis on the Development of Fine Arts in Heilongjiang [J], Journal of Heilongjiang College of Education, 2013, 32(6)

[4] Li Kejing, Wang Ting. Discussion on the Significance of Folk Fine Arts on Art Education System in Local Universities [J], Art Education Research, 2015(3): 120-121

[5] Han Jiqiang. The Development of Fine Arts in Heilongjiang under the Diversified Context of Contemporary Fine Art in China $[\mathrm{J}]$, the Border Economy and Culture, 2014(9): 145-146. 